\title{
Transition from Remote Indigenous Community to Boarding School: The Lockhart River Experience
}

\author{
Richard Stewart
}

Brian Lewthwaite

James Cook University

etropic 14.1 (2015): 91-97. http://www.reefandleaf.com.au/etropic.html \& http://www.jcu.edu.au/etropic

\begin{abstract}
The transition to boarding school for students from the remote Indigenous community of Lockhart River on Cape York is a fact of life when they complete Year 7. With the transition to boarding school, Lockhart River mirrors remote Indigenous communities throughout Cape York and the Torres Strait, and remote regions in South Australia, Western Australia and the Northern Territory. Access for remote Indigenous students to quality education provision in major urban centres is a key element of government policy in addressing disadvantage in education outcomes between Indigenous and non-Indigenous students. Despite this, there is little in the way of recent research into the transition process in terms of its effectiveness in ensuring the delivery of a quality secondary education. The proposed study will use qualitative methods to examine the transition from a remote Indigenous community from the perspective of the students and their parents and care-givers.
\end{abstract}

\section{Introduction}

Each year over 500 Indigenous students from Cape York in Far North Queensland and the communities of the Torres Strait leave their home communities to attend boarding school in a variety of locations in Queensland and interstate. A significant number of these students do not successfully complete their first year of studies away from home, let alone their Year 12 studies. For them, the experience of being away from their families and home communities, their school and boarding school experience sees them prematurely disengaged from formal education returning to their home communities where their options with respect to formal education are severely limited. While there are a range of financial, material and human supports available to students in making the transition from remote communities to boarding school, there is little evidence of any rigor around an assessment of these supports, especially from the perspective of students and their families. Further to this, there has been little in the way of recent research which points to any searching analysis of the quality of boarding school providers in terms of their capacity to successfully engage, retain and educate the Indigenous children in their care. This paper outlines the background to this context, provides a review of the literature in this area and describes the proposed study. 


\section{Transition to Boarding: The Literature}

The body of current literature on Indigenous education is vast. Indigenous education, or more precisely the issues around the disparities in educational outcomes between Indigenous and non-Indigenous children, features regularly and prominently in the Australian media, particularly in The Australian and in a range of scholarly journals such as the Australian Journal of Indigenous Education. However a search of the current literature pertaining to the transition to boarding school for Indigenous students from remote communities reveals significant gaps in terms of contemporary research. There is little in the way of reliable data, neither qualitative nor quantitative as to the effectiveness and impact of the transition process, despite the fact that for many Indigenous children in Queensland, Western Australia, South Australia and the Northern Territory, boarding school presents the only opportunity for a comprehensive secondary education.

The lack of contemporary research literature is exemplified by Biddle (2011) who states that there are a number of important school-related research questions that we really know very little about. In terms of this research, the most significant question he presents is, "Do Indigenous children who attend boarding schools in cities as opposed to their local schools in regional or remote areas have better outcomes than if they stayed where they were?”(p.22) Biddle's assertion has been challenged by prominent Indigenous leader Noel Pearson who states that, "Almost all of the Indigenous people who have succeeded in education and who have gone on to make a leading contribution on behalf of their people were educated at boarding schools often a long way from their homes, most often at church schools. In Cape York Peninsula, no Aboriginal tertiary graduates have come from local secondary schools It is on this past practice-its successes as well as its failures - that we base our policy in Cape York Peninsula: scholarships to high-quality, high-expectations secondary schools down south" (Pearson, 2011, p.298-299). His view, which is perhaps based on his own experience of boarding school and is not supported by any published reliable data, is one shared by current Commonwealth Indigenous Affairs Minister Nigel Scullion who has stated that "The evidence of education and, as a consequence, employment outcomes achieved by Indigenous children who attend boarding schools is indisputable” (Australian Newspaper, Feb. 13, 2014).

The gaps in the research literature were highlighted a decade ago by the Queensland Indigenous Education Consultative Body (QIECB) who released a discussion paper on boarding schools which stated that there was a clear need for research to be undertaken on "how boarding school policies and strategies impact upon Aboriginal and Torres Strait Islander students and their communities including the identification of policy gaps and effective strategies"(2004, p.2). It is a view later reinforced by the New South Wales Catholic Education Commission in 2008 in a discussion paper entitled 'Supporting Aboriginal Students Being Schooled Away from Home.' While focusing on the needs of Aboriginal students from regional rural New South Wales, the Commission stated that "while there is an abundance of media comment about Aboriginal and Torres Strait Islander students being educated away from home, there has been very little academic research in this area” (p.4).

It is a situation which exists to this day: an abundance of media comment, especially that which supports the outcomes attributed to elite boarding scholarship programs, 
and, with one important exception, a lack of rigorous independent research of a qualitative or quantitative nature which has a distinct focus on Indigenous students from remote communities who transition to boarding schools. The exception is in the form of David Mander's 2012 doctoral thesis, 'The Transition to Boarding School for Male Aboriginal Secondary School Students from Regional and Remote Communities Across Western Australia.' Echoing the previously stated issues around the availability of appropriate research in the field, Mander states that "despite the breadth of debate as well as decades of State and Federal awareness to the needs of Aboriginal families in regional remote communities, little research has exclusively explored the experience of Aboriginal children studying away from home at boarding school” (2012, p.9). While not focusing exclusively on students from remote Indigenous communities, Mander's work is important for a number of reasons. Chief among these is his focus on researching perspectives on transitions of students, parents and the staff of boarding schools. His research provides great insights into the way in which participants in the transition process perceive the move from a rural or remote environment into one which is different on so many fronts. Both students and parents viewed the move away from community to Perth as an opportunity to succeed , despite concerns about homesickness, culture shock and, in the case of students from the warmer climates of the Pilbara and the Kimberley, 'climate shock' (2012, p.153).

The contemporary importance of the role to be played by boarding schools or residential facilities in addressing Indigenous educational disadvantage is best exemplified by the recent Wilson Review in the Northern Territory. Given the increasing urgency expressed by governments at both Federal and State/Territory level to 'do something' about the current state of Indigenous education, the review merits a closer examination as an important contribution to the existing literature, despite the fact it presents no new data about the impact of boarding on outcomes for remote Indigenous students.

\section{Transition as the Norm: The Wilson Review in the Northern Territory}

Presented to the Northern Territory Government in 2014, the Review of Indigenous Education in the Northern Territory prepared by education consultant Bruce Wilson devotes significant space to discussions regarding the inadequacy of secondary education provision in remote locations and the subsequent need to focus on boarding in regional locations as 'the solution' to improving education outcomes across the board for students from remote communities. The review states that "despite reservations, there is now a growing view that residential and boarding facilities are a viable solution" (2014, p.147). In a rather revealing comment on the inadequacy of any real research or evidence base, the review goes on to state that "in the longer term, it is anticipated that residential facilities will become increasingly acceptable once good data and information are available about their effect on student achievement” (2014, p. 149). Given that Indigenous students have been leaving remote communities to attend boarding schools for decades it is somewhat surprising that as late as 2014 we are still waiting for data to become available.

The Wilson Review is significant in this context for a number of reasons. There is reference to 'anecdotal accounts' of how students attending boarding facilities have encountered significant issues with homesickness and a host of other barriers which 
impacted upon their ability to complete secondary studies but no reference to credible research upon which to validate the anecdotal accounts. The Northern Territory Government has seized upon the review recommendations in allocating \$40 million over 5 years for the development of boarding facilities in urban and regional centres in order that students from remote communities will be able to take advantage of more comprehensive secondary offerings than those available in their home communities. The decision with respect to such a significant resource allocation has been made without reference to research data that can articulate what works best in the boarding context, apart from the mandatory references to Noel Pearson and his views that quality secondary education in the bush is an unattainable dream. There is certainly no reference in the Wilson Review to any research which articulates the experience of community members of the Northern Territories remote communities, including the experiences of the children who have gone way to board.

\section{The Research Questions}

At the core of the proposed research is an examination of how it is that the key participants in the transition process; especially students and their families, view the move away from their home community to boarding school. There is a clear intention to privilege the voice of those involved. The central research question that will be addressed through this research is then: How is the transition experience from home community to boarding school experienced by those involved - especially the students and their parents and caregivers?

From this central question there are a number of guiding questions which will shape how this research is able to capture the totality of the transition experience of children from one remote Cape York community, Lockhart River, to boarding school. These questions are:

1. How do those that are about to experience the transition view the prospects of going to school away from Lockhart River?

2. What is the lived experience of those that experience the transition to boarding school?

3. What do the children themselves, their parents and care-givers, believe are the factors which make for successful transition?

\section{Why Lockhart River?}

The remote Indigenous communities of Cape York in Far North Queensland experience educational outcomes well below those of the rest of Australia. By any measure, Lockhart River community is one of the remotest communities in Australia and it features highly on a considerable number of indicators socio-economic disadvantage. Located approximately 800 kilometres north of Cairns, it is classified using Australian Bureau of Statistics criteria as 'very remote.' It is a community, which is in my direct experience, passionate about achieving the best for its children. It is committed, within its capability, to achieving the best means of ensuring that the children of Lockhart River have the best possible experience with education, both inside and outside of the community. Education policy-makers have determined that transition to boarding school at the end of primary school will be the educational norm for remote Cape York communities such as Lockhart River and that a limited 
secondary program will only be made available to children who return to the community when the transition fails. In 2015, the transition to boarding school will occur a year earlier and students will leave the community at the end of Year 6.

In a policy and resource sense the supports are there to allow children from the community to access a quality secondary education 'down south.' The reality is however, that a significant number of those who leave Lockhart River community to be educated, exit secondary school prematurely. There is a pressing need to articulate why this happens and to provide community-driven solutions which are based on valuing the knowledge and experience of the participants in the transition process.

\section{Intent and Significance of the Proposed Research}

The key purpose proposed research is to provide a body of contemporary qualitative data regarding the transition of children from the remote Indigenous community of Lockhart River on the Cape York Peninsula in far north Queensland to secondary boarding school. While the research will have a focus on one particular community, it is anticipated that it will provide information and articulate a process which may well be transferrable to the remote context in other parts of Australia, such as the island communities of the Torres Strait, Gulf, Arnhem Land and the Top End, Central Australia, Kimberley and APY Lands of South Australia. There is significant scope for research in the Cape York context to validate the assumption that the transition to boarding school is highly problematic for many children from Lockhart River and other communities and a similarly pressing need to present the experience of the transition in a manner which both humanizes and validates the perspectives of the participants. It must be remembered that for many Aboriginal and Torres Strait Islander children (and their families and communities) a comprehensive secondary education will likely never be offered in their remote home communities. Indeed, if the essential thrust of the Wilson review is accepted in jurisdictions outside the Northern Territory, it is likely that secondary education offerings will be cut further.

It is therefore essential that the policies relevant to the transition to boarding school and the resource and program offerings which stem from them are based upon data derived from independent and rigorous research.

\section{Data Sources}

The most important single data collection method to be used in the research will be the qualitative interview which, in its desired relational and conversational style, will be conducted using semi-structured on unstructured style. Yin (2011) states that in qualitative research it is highly likely that the qualitative interview will be the dominant mode of data collection, and, in this study, will be carried out using openended rather than closed-ended questions (p.135). Given that perspectives on the transition to boarding school will be sourced from different participants in differing situations it is important that the style, structure and setting for the interviews be flexible and appropriate. The analysis of documents relevant to the transition to boarding school will comprise an important source of data for the research. The documents to be assessed would include policy documents produced by schools and government authorities which are relevant to the boarding context including handbooks and promotional material and correspondence such as letters from schools 
which would be generated at times when suspension, exclusion or expulsion processes are enacted. Merriam (1998) highlights the importance and relevance of documentary data as "particularly good sources for qualitative case studies because they can ground an investigation in the context of the problem being investigated" (p.126). The value of documents is further highlighted by Yin (2004) who states that they can prove invaluable in the context of the qualitative study and provide important contextual information to complement work done in the field.

\section{Conducting the Research}

The 2015 cohort leaving Lockhart River is made of boys and girls entering boarding school in Year 7 and year 8. As of November 2014, there were 18 students in the cohort, of whom 16 had almost completed their preparations for the transition, having secured places at boarding schools in Cairns, Townsville, the Atherton Tablelands and Brisbane. The first round of interviews, all of which are conducted in the community, are intended to capture the sense of anticipation and expectation about the soon to occur transition to boarding school and will occur in January 2015. Subsequent interviews will be conducted in community during term breaks at the end of Term 1 and Term 2. An Indigenous Advisory Group, made up of community members has been constituted to assist with the conduct of the research which has the support of the Lockhart River Council and the Puya Foundation, an organization which supports education and community development activities in Lockhart River. Ethics approval for the conduct of the research was granted in October 2014. Conclusion

There is a clearly articulated view in the Australian media that remote Indigenous communities in Australia are in crisis in terms of indicators pertinent to education, health and employment. The Commonwealth and State and Territory governments have committed significant resources to addressing issues around attendance and literacy and numeracy, particularly for primary school students. The Remote Attendance Strategy, a key focus of Prime Minister Abbott and Indigenous Affairs Minister Scullion, has attracted significant financial and human resources with only sporadic gains in attendance across a range of remote communities.

While the data and the research base relevant to primary school education receives significant attention, the same cannot be said for the situation with respect to secondary education, especially secondary education which is delivered in boarding schools located often thousands of kilometers away from students' home communities. Media comment is one thing. Serious attention to a phenomenon which has received very little attention in the way of serious research is another. It is clear that there exists significant scope for research which privileges how the transition to boarding school is experienced by the students and families most directly affected by it given that successful transition to boarding is increasingly viewed by policy makers as the solution to improving outcomes for many of Australia's most disadvantaged students. 


\section{Works Cited}

Australian Bureau of Statistics. (ABS). (2010). Population characteristics, Aboriginal and Torres Strait Islander Australians (ABS publication No. 4713.0).

Australian Government (2012). Cape York Welfare Reform Evaluation 2012.

Australian Institute of Aboriginal and Islander Studies (AIATSIS) (2000). Guidelines for ethical research in Indigenous studies. IATSIS , Canberra.

Biddle, N., CAEPR Indigenous Population Project 2011 Census Papers, Paper 8 Education Part 2 : School Education, Centre for Aboriginal Policy Research, Research School of Social Sciences, ANU College of Arts and Social Sciences.

Catholic Education Commission N.S.W. (2008). Supporting Aboriginal Students being Schooled Away from Home: A discussion Paper for N.S.W. School Authorities.

Chilisa, B. (2012). Indigenous Research Methodologies. Thousand Oaks CA: Sage.

Karevlis, P., Ferrari, J. (2013). Noel Pearson is Tony Abbott's man to fix schools. Australian Newspaper, September 29, p.1.

Mander, D. (2012). The Transition to Boarding School for Male Aboriginal Secondary School Students from Regional and Remote Communities across Western Australia. PhD Thesis. Edith Cowan University, Western Australia.

Martin, S. (2014), Scullion flags boarding school for Indigenous students, Australian Newspaper, February 13, 2014.

Merriam, S. (1998). Qualitative Research and Case Study Applications in Education. San Francisco: Josey Bass.

National Health and Medical Research Council (NHMRC). (2003). Values and ethics: Guidelines for ethical conduct in Aboriginal and Torres islander research. Canberra. Commonwealth of Australia.

Pearson, N. ( 2011). Radical Hope: Education and Equality in Australia. Collingwood: Black Inc.

Pearson, N. (2011). Up From the Mission: Selected Writings. Collingwood: Black Inc.

Purdie, N., Buckley, S., (2010). School attendance and retention of Indigenous Australian students. Issues Paper 1 Closing the Gap Clearinghouse, Australian Institute of Health and Welfare. Canberra.

Queensland Indigenous Education Consultative Committee, (2000). Position Paper Boarding Schools.

Wilson, B. (2014). A share in the future: Review of Indigenous Education in the Northern Territory.

Yin, R. (2009). Case Study Research Design and Methods. Thousand Oaks, CA: Sage.

Yin, R., (2011). Qualitative Research from Start to Finish. New York: Guilford Press. 